\title{
Fuelwood availability and use in the Richtersveld National Park, South Africa
}

\author{
C.M. Shackleton, G. Guthrie, J. Keirungi and J. Stewart
}

Shackleton, C.M., G. Guthrie, J. Keirungi and J. Stewart. 2003. Fuelwood availability and use in the Richtersveld National Park, South Africa. Koedoe 46(2): 1-8. Pretoria. ISSN 0075-6458.

Concern has been voiced about the possible over-use of fuelwood from the riparian fringe by pastoralist herders in the Richtersveld National Park (RNP). This coincided with the current examination and modelling of the supply and use of ecosystem goods and services in the Gariep Basin as part of the Southern African Millennium Assessment (SAfMA). This paper reports on a study to index the current availability of deadwood within the riparian zone of RNP, its relationship with proximity to human habitation, and species preferences of the local herders. Deadwood availability was assessed per woody species and on the ground in 12 transects within the riparian fringe. Herders were interviewed regarding their species preferences, and the composition of woodpiles was examined. There was no relationship between the percentage of attached deadwood on the tree, or the percentage deadwood ground cover, and the distance from herder stockposts. Euclea pseudobenus and Tamarix usneoides were the dominant species in the riparian fringe. There was strong selection for Ziziphus mucronata as a fuelwood species and only marginal or random selection for E. pseudobenus. Tamarix usneoides and Prosopis sp. were abundant in the riparian zone, but were not used for fuelwood. There was a significant difference between species with respect to the mean proportion of the stem that was dead, the highest being $Z$. mucronata ( $\pm 28 \%$ deadwood), followed by T. usneoides $( \pm 12 \%)$. Most of the Prosopis trees had no deadwood. Across all species, the mean percentage dead per tree was approximately $15 \%$. Additionally, detached deadwood covered just less than $9 \%$ of ground area, averaged across all plots and transects. All the variables measured indicated that there seems to be little need for concern over the current fuelwood extraction activities of pastoralists within the RNP. There was no clear evidence of cutting of branches or deadwood. The abundance of both attached and detached deadwood was not depleted close to human habitation. There was still abundant deadwood, even on preferred species. The most preferred species (Ziziphus mucronata) had the greatest mean proportion of deadwood. The herders stated that they only used deadwood, and that there was plenty. They rarely used driftwood washed down the river, although there was an abundance of it. Thus, overall, there was no sign of depletion of the deadwood resource, even on favoured species, or degradation of the productive capacity for deadwood.

Key words: deadwood; fuelwood; preference; riparian fringe; selection

C.M. Shackleton (c.shackleton@ru.ac.za), G. Guthrie, J. Keirungi and J. Stewart, Department of Environmental Science, Rhodes University, Grahamstown, 6140 South Africa.

\section{Introduction}

Fuelwood is the dominant energy form throughout southern Africa and the rest of the developing world (Gielink 1991; Hall 1991; Pandey 2002). This has consequences for human well-being as well as environmental quality. In terms of the latter, large-scale use of fuelwood has often been implicated in deforestation and desertification, with many historical official reports demanding interventions to limit perceived environmental damage, before total denudation occurred (Leach \& Mearns 1996; Sullivan 1999; Dahlberg 2000). This became known as the fuelwood crisis; based on fuelwood gap 
models portraying that fuelwood supply was diminishing in the face of increasing demand from growing human populations, and that ultimately there would be insufficient fuelwood to meet human needs with attendant severe environmental degradation.

The notion of a fuelwood crisis has been questioned in recent times (e.g. Leach \& Mearns 1989; Benjaminsen 1997; Nagothu 2002; Pandey 2002), primarily because the predictions of the models frequently failed to materialize. The failure of model predictions can be ascribed to a number of limitations in the original models, the primary ones, amongst others, being (i) failure to account for changes in consumer patterns with increasing scarcity, (ii) overlooking the contribution of wood from arable and residential areas, (iii) the strong coppicing ability of most woodland species and the faster growth rates of regrowth from cut stumps than from seedlings, (iv) tree yield and growth models taken from commercial forestry equations for harvestable timber, and therefore excluding smaller branches and twigs, and wood that would be unsuitable for timber, but acceptable as fuelwood, and (v) unrealistic time frames to models. The further the model was required to project into the future, the greater was the magnification of weak measurement precision and model assumptions.

Within South Africa the majority of the rural population make extensive of fuelwood, despite increased electrification in the last decade. Annual demand is approximately 11 million tons (DME 1996), well within sustainable supply at a national level (Williams \& Shackleton 2002). However, in many areas there is a severe imbalance between demand and supply for fuelwood at a localised scale resulting in progressive deforestation. This is most apparent in areas of high human population density, although not ubiquitous to them all (Banks et al. 1996).

Within this context, some conservationists have raised concerns about the possible over-use of fuelwood as the primary energy source of pastoralist herders in the
Richtersveld National Park (RNP) (Hendricks pers. comm.). Within South Africa the RNP is unusual in that, despite being a protected area, there are 26 permanent households who graze 6600 small livestock and who depend upon the environmental goods and services offered by the habitats of the RNP for many of their daily needs (Hendricks pers. comm.). This includes fuelwood. Whilst the RNP is a contractual park (a 30 year lease agreement from the Nama community by the South African National Parks (SANP) for conservation purposes), SANP is mandated with biodiversity conservation, and therefore seeks to ensure that landuses within RNP have minimal impact. Hence the need to examine the use of fuelwood. This coincided with the current assessment and modelling of the supply and use of ecosystem goods and services in the Gariep Basin as part of the Southern African Millennium Assessment (SAfMA). The RNP represents one of the core study sites for the local level assessments of the SAfMA, and fuelwood is one of the indicators of ecosystem status across all SAfMA sites.

For the RNP pastoralists, the riparian fringe of the Gariep River, which forms the northern boundary of the park, is a key resource area in an extremely arid environment. During summer, the herders temporarily occupy stockposts within one kilometre of the river. They rotate from one stockpost to another every two to four months. The location of stockposts is fixed and permanent, but use thereof is periodic. In the winter months the herders move to the 'buiteveld'; towards the centre of the park and away from the Gariep River. During this time the bulk, but not all, of their fuelwood is still collected from the riparian fringe and transported to the buiteveld stockposts (Hendricks pers. comm.). This is supplemented with biomass from dry shrubs, especially Zygophyllum prismatocarpum.

Because of the concentration of fuelwood collection along the riparian fringe in RNP it can be assumed that the environmental impacts of wood use would be most apparent along the riparian zone. Additionally, since it 
has been shown in numerous studies (e.g. Grundy et al. 1993; Banks et al. 1996; Luoga et al. 2001) that fuelwood collection is most intense close to human settlements rather than further away, it can be hypothesized that if there is insufficient fuelwood for herders in RNP, then a zone of depletion would be apparent radiating out from the stockposts. Such a zone of depletion would be manifest as a reduced standing crop or abundance of fuelwood close to stockposts, as well as possibly increased signs of chopping or breakage on preferred species. The presence of such a zone would indicate that deadwood production was insufficient to meet localized demand, and hence the spatial extent of environmental impacts could be expected to gradually increase in the near term. This would not, however, imply that all wood would ultimately be depleted, because human and livestock population numbers within the RNP are limited by the contractual agreement.

This paper reports on a study to index the current availability of deadwood (as the favoured fuelwood resource) within the riparian zone of RNP, its relationship with proximity to stockposts, and species preferences of the local herders. It sought to index the harvesting impact of local communities on the deadwood resource, without developing data- and time- intensive supply and demand models. As such the study attempted to provide support or negation for SANP's concerns regarding potential negative impacts of fuelwood extraction activities.

\section{Study area}

The RNP is a contractual park located in the semi-arid region of the Namaqualand magisterial district in the northwestern part of South Africa, bordering onto Namibia. It is regarded as the only true mountain desert in South Africa, and is managed jointly by the local Nama people and the South African National Parks. The Richtersveld experiences an arid climate. Most of the region receives winter rainfall (May to September), but summer rainfall is not uncommon.
Between 1995-2001, the mean annual rainfall in the Richtersveld National Park was $82 \mathrm{~mm}$, with rainfall variability tending to decrease from east to west and from south to north, although the varied topography increases the spatial variability in rainfall (Hendricks pers. comm.). As is typical in arid environments, the RNP experiences massive temperature fluctuations from over $50{ }^{\circ} \mathrm{C}$ in the summer to freezing point on some winter nights.

The RNP is widely known as one of the world's most succulent-rich areas. This richness can be attributed to the large number and diversity of habitats in the area (Van der Walt 1992). The vegetation of the park has evolved within a water-stressed environment and is thus mainly succulent, comprising more than 700 species of herbs, shrubs and trees, geophytes and annuals (Williamson 2000). It is estimated that 50 genera out of the total of 160 from the Mesembryanthemaceae family occur in RNP (Van der Walt 1992). None of the preferred fuelwood species have a significant conservation status, in that none are listed as rare, endangered or endemic.

There are 26 households resident within the RNP. They are nomadic pastoralists, rotating their herds of goats and sheep within the park in response to availability of forage. Wood is their primary energy source for cooking and warmth. Fires are made in the open or behind makeshift windbreaks. There is no trade in fuelwood. Visitors to the RNP are expected to supply their own energy requirements.

\section{Methods}

\section{Deadwood availability}

The availability of both attached (still on tree) and detached (on ground) deadwood was assessed along 12 line transects in the riparian fringe parallel to the Gariep River and radiating away from eight herder stockposts. Each line transect consisted of 20 points $50 \mathrm{~m}$ apart (hence $1 \mathrm{~km}$ in total length), with the first point being $50 \mathrm{~m}$ from the stock post. At each point 
the nearest tree was examined and records made of (i) the species, and (ii) a visual estimation of the proportion dead. The proportion was first estimated in terms of one of eight classes using the scale of Walker (1976). Once the class was established, which provided upper and lower limits for the visual estimation thereby reducing variability, a final percentage dead was estimated. In addition, a five by five metre quadrat was marked out, to the left and front (in the direction of the transect) of the sample point. A visual estimation of the percentage of detached deadwood cover (branches on the ground) was made in these quadrats. Detached deadwood included that from the trees in the riparian fringe, as well as driftwood debris deposited by the Gariep River.

Sampling was restricted to the riparian fringe since tree biomass is relatively limited throughout other areas of the RNP. This is well appreciated by the resident pastoralists, who stated that even when they moved away from the river in winter, fuelwood is transported from the riparian fringe by motor vehicle (Hendricks pers. comm.). In terms of fuelwood species preferences expressed by the herders, the majority are found only in the riparian fringe, and not inland in RNP, other than Zygophyllum prismatocarpum.

\section{Species preferences}

Four pastoralist herders within the RNP were opportunistically interviewed to determine the species preferences with respect to fuelwood. A semi-structured interview was used to gather data on preferred species, species used and wood collection methods. The interview approach had no fixed wording or ordering of questions (Case 1990). This allowed for flexibility in that it is possible to seek clarification and elaboration on some of the answers given (Martin 1995). Three fuelwood piles were inspected and the species identity of each stick/log was recorded to provide quantitative data regarding preferences.

\section{Data analyses}

Woody plant species composition along the riparian fringe was determined as the percentage occurrence (as the proportion of total stems sampled) of different species along the transects. The relative proportion of species present was compared to the relative proportion of species found in the herders' woodpiles. A ratio of availability to use was then used to indicate selection or avoidance of specific species. If the ratio was greater than one for a specific species, then active selection was indicated, if less than one, then avoidance, and a ratio of approximately one indicated use was random for that species (Shackleton et al. 1994).

The influence of distance from stockposts on attached and detached deadwood availability was examined via linear regression. Differences in the proportion of attached deadwood per species were tested using a Kruskal-Wallis Anova after arcsine transformation of the original percentage data. Only those species constituting $5 \%$ or more of the frequency data set were included as the occurrence of species with lower frequency was superfluous because of their low sample number.

\section{Results}

There was no relationship $\left(r^{2}=0.02 ; n=20\right.$; $p>0.05$ ) between the percentage of attached deadwood on the tree, and the distance from the stockpost (Fig. 1).

Similarly, there was no relationship $\left(r^{2}=\right.$ $0.0003 ; n=20 ; p>0.05)$ between the percentage cover of detached deadwood on the ground and the distance from the stockpost (Fig. 2).

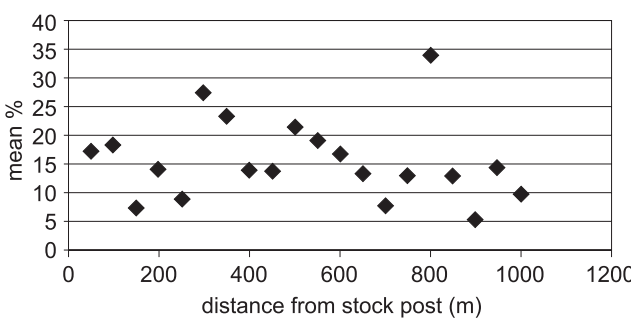

Fig. 1. Mean percentage deadwood per tree in relation to distance from stockpost ( $n=12$ transects).

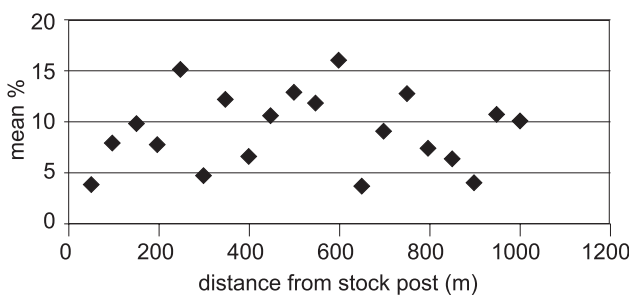

Fig. 2. Mean percentage deadwood cover on ground in relation to distance from stockpost ( $n=12$ transects). 
Damage to trees (cutting or breakage) was observed on only six of the sampled trees, where a branch had been bent back. It was not possible to tell the cause of the break, whether human or perhaps baboons.

\section{Species selection}

Ziziphus mucronata and E. pseudobenus were the preferred species for fuelwood collection, dominating with $45 \%$ and $34 \%$ respectively (Table 1 ).

Overall, eleven tree species were encountered during the survey, but several were represented by only a single individual. Those representing greater than $5 \%$ of the stems sampled are presented in Table 2. Euclea pseudobenus and T. usneoides were the dominant species in the area, comprising $31 \%$ and $32 \%$, respectively.

There was strong selection for Z. mucronata and only random selection for $E$. pseudobenus (Table 3). Ziziphus mucronata was also the principal fuelwood species. T. usneoides and Prosopis sp. were common species in the riparian zone, but were absent from woodpiles, indicating that they were actively avoided. The interview responses confirmed that harvesters did not make use of these two species.

\section{Proportion of deadwood per species}

There was a significant difference $(S=43.2$; $p<0.001$ ) between species with respect to the mean proportion of the stem that was dead. On average, more than one quarter of
Z. mucronata trees were dead, which was more than double the amount of deadwood of the next closest species, i.e. T. usneoides (Table 4). Most of the Prosopis trees had no deadwood at all. Across all sites and species, the mean percentage dead per tree was approximately $15 \%$. Additionally, detached

Table 1

Composition of fuelwood piles

\begin{tabular}{lc}
\hline Species & Percentage \\
\hline Ziziphus mucronata & 45 \\
Euclea pseudobenus & 34 \\
Unknown \# & 21 \\
\hline
\end{tabular}

\# The unknown species was one unidentifiable species, and not a combination of more than one species.

Table 2

Species composition along the riparian fringe

\begin{tabular}{lc}
\hline Species & Percentage \\
\hline Tamarix usneoides & 32 \\
Euclea pseudobenus & 31 \\
Ziziphus mucronata & 20 \\
Prosopis sp. & 6 \\
All others combined (each less than 5\%) & \\
(Acacia karroo, Maytenus linearis, & \\
Nicotiana glauca, Rhus pendulina, & \\
plus unidentified species) & 11 \\
\hline
\end{tabular}

Table 3

Preference ratios

\begin{tabular}{lcccc}
\hline Species & $\begin{array}{c}\text { \% in wood } \\
\text { piles }\end{array}$ & $\begin{array}{c}\text { \% in } \\
\text { environment }\end{array}$ & Ratio & Preference \\
\hline Ziziphus mucronata & 45 & 20 & 2.25 & Preferred \\
Euclea pseudobenus & 35 & 31 & 1.13 & Random \\
Tamarix usneoides & 0 & 32 & 0 & Avoided \\
Prosopis sp. & 0 & 6 & 0 & Avoided \\
\hline
\end{tabular}


deadwood covered just less than $9 \%$ of ground area, average across all plots and transects.

Table 4

Mean percentage $( \pm S E)$ deadwood on each tree species

(Unlike letters are significantly different)

\begin{tabular}{lcc}
\hline Species & Mean \% deadwood per stem \\
\hline Ziziphus mucronata & $27.8 \pm 5.4$ & $\mathrm{a}$ \\
Euclea pseudobenus & $8.8 \pm 2.4$ & $\mathrm{~b}$ \\
Tamarix usneoides & $12.2 \pm 2.9$ & $\mathrm{~b}$ \\
Prosopis sp. & $0.3 \pm 0.2$ & $\mathrm{~b}$ \\
\hline
\end{tabular}

\section{Discussion}

There is some concern among conservationists regarding the threat that the local pastoralists pose to conservation in the RNP $(\mathrm{H}$. Hendricks pers. comm.). The pastoralists use a variety of natural resources for their livelihood, from grazing their herds, to the use of wood for construction and fuel, use of medicinal plants, and fishing. In terms of fuelwood extraction, we have demonstrated that, despite the rudimentary nature of the study, all the variables measured indicated that there seems to be little cause for concern over the current fuelwood extraction activities of pastoralists within the RNP. There was no evidence of cutting of branches or deadwood. The availability of both attached and detached deadwood was not depleted close to human settlement (stockposts), relative to further away. There was still abundant deadwood, even of preferred species. The most preferred species (Ziziphus mucronata) had the greatest mean proportion of deadwood. Moreover, of the two most common species in the riparian zone, one was not a favoured species (Tamarix unsneoides) and the other (Euclea pseudobenus) was not actively selected for, as indexed through the ratio of the proportions in the environment and fuelwood piles. The four herders interviewed stated that they only used deadwood, and that there was plenty. They did not have to walk far to collect deadwood for their daily needs. None of the four interviewees felt that there had been any decline in the availability of deadwood over the last five to ten years. They rarely used driftwood washed down the river, although there was an abundance of it. Thus, across all these indices, there was no sign of depletion of the deadwood resource, even on favoured species, or degradation of the productive capacity for deadwood.

This finding conforms to other recent work in arid environments questioning the notion and severity of degradation by low density populations of pastoralists (Reid \& Ellis 1995; Sullivan 1999; Ward et al. 2000; McNeely 2003). It also mirrors the rationale and findings of the study by Abbot \& Homewood (1999) of fuelwood use in Lake Malawi National Park. There too, conservation management considered domestic fuelwood use by people residing in the park to be the primary cause of miombo woodland decline within the park. But, quantitative analysis of supply and demand demonstrated that domestic fuelwood demand was well below the sustainable annual production of deadwood in Lake Malawi National Park, and demand for wood for commercially driven fish smoking enterprises was the primary cause.

Whilst our study has shown there to be little cause for concern at present, it is possible this may change in the future, although unlikely in the near term because of the low and controlled number of residents in the park and the seemingly high abundance of deadwood relative to current demand. However, since the residents in the park practice a nomadic lifestyle it is likely that fuelwood will remain their primary energy source for years to come. Therefore, it may be desirable for conservation management to engage in a process of defining, with the residents, thresholds of potential concern and indicators of decline, which could be monitored at an appropriate frequency. A more detailed study of deadwood production and use may also be desirable. 
Overall, only 11 tree species were recorded in the line transects, providing only limited choice to the fuelwood collectors. Of these, two (E. pseudobenus and Z. mucronata) contributed the bulk of the wood in the fuelwood piles, as well as mentioned during the interviews. Both of these have relatively dense wood, which is ideal for cooking fires (Tietema et al. 1991; Abbot \& Lowore 1999; Kataki \& Konwer 2002), since it has a higher energy content, burns slowly but with even heat, and makes good coals. In comparison, although T. usneoides was common and had more deadwood per stem than $E$. pseudobenus, it was actively avoided, which may be a consequence of its wood being light and brittle and therefore unsuitable for cooking fires. Interestingly, Goel \& Behl (2001), in a study assessing the relative potential of various hardwood species for fuelwood production, found Prosopis juliflo$r a$ to be the most promising species in terms of biomass productivity and Fuel Value Index. Additionally Prosopis spp. are widely used in other parts of the Northern Cape province as fuelwood (C. Fabricius pers. comm.) Yet, in RNP, Prosopis sp. was not used, as measured in the fuelwood bundles and supported by the interviews. This is possibly related to the negligible amounts of deadwood found on Prosopis sp. in RNP $(<1 \%)$. Deadwood is invariably favoured over live wood as a fuelwood resource where a choice is possible, i.e. where deadwood has not been totally harvested, which was the case in RNP.

The difference in deadwood availability between species was noteworthy, and little studied in the literature pertaining to fuelwood. Typically, the fuelwood production capacity of different species has been tacitly assumed as uniform, or simply to mirror the growth rates of the live tree. Previously, estimates of production of deadwood have been area based rather than tree based (Shackleton 1998; Abbot \& Homewood 1999). In comparison, Mudekwe (1997) examined species differences in both standing crop and production of deadwood in the Limpopo lowveld and found marked differences between tree size classes and the five species investigated. This needs to be examined at other sites. Additionally, the productive capacity of fuelwood in RNP has a patchy distribution, being largely limited to disjunct strips along the riparian fringe. This means that coarse-scale studies and models would underestimate the availability of fuelwood, which must also influence subjective impressions about the sustainability of fuelwood use.

The study focussed solely on the availability of deadwood. We did not examine aspects relating to its role in ecosystem function, such as nutrient cycling or provision of habitats for microfauna and flora, although the importance of such a role has been questioned in southern African savanna ecosystems where collection is by hand (Williams $\&$ Shackleton 2002). Nonetheless, the clear abundance of deadwood with RNP under the current harvesting arrangements, allows us to hypothesize that impacts relating to ecosystem function would be well within acceptable limits, but this needs to be tested. This is so even from a biodiversity conservation perspective in light of the need to maintain a cooperative and beneficial relationship with the Richtersveld people, from whom the land is leased for conservation purposes.

In summary, this study could not substantiate verbal concerns relating to the possible overexploitation of deadwood within RNP. It appears that current extraction levels are low relative to the availability, and hence can be accommodated within the broader conditions pertaining to the lease arrangements and management of this key biodiversity area.

\section{Acknowledgements}

We gratefully acknowledge the assistance of Howie Hendricks in orientating us within RNP and facilitating interviews with pastoralists. This study formed part of, and was partially funded by, the South African component of the Southern African Millennium Assessment, which focuses on ecosystem goods and services in the Gariep Basin. Useful comments were received from Christo Fabricius and three anonymous reviewers on earlier drafts of this paper, for which we are appreciative. 


\section{References}

Аввот, J.I.O. \& K. Homewood. 1999. A history of change: causes of woodland decline in a protected area in Malawi. Journal of Applied Ecology 36: 422-433.

Aввот, P.G. \& J.D. Lowore. 1999. Characteristics and management of some indigenous firewood species in Malawi. Forest Ecology and Management 119: 111-121.

Banks, D.I. Griffin, N.J., Shackleton, C.M., Shackleton, S.E. \& J.M. MAVRANDONIS. 1996. Wood supply and demand around two rural settlements in a semi-arid savanna, South Africa. Biomass \& Bioenergy 11: 319-331.

BENJAMINSEN, T.A. 1997. Is there a fuelwood crisis in Mali? Geojournal 43: 163-174.

CASE, D.D. 1990. The community's toolbox: the idea, methods and tools for participatory assessment, monitoring and evaluation in community forestry. Rome: Food and Agricultural Organization (FAO).

DAHLBERG, A.C. 2000. Interpretations of environmental change and diversity: a critical approach to indications of degradation: the case of Kalakamate, northeast Botswana. Land Degradation \& Development 11: 549-562.

Department of Minerals AND EnERgy AfFairs, 1996. Energy in South Africa. Pretoria: Government Printer.

GiELINK, M.I. 1991. Energy in southern and eastern sub-Saharan Africa. Journal of Energy Research \& Development in South Africa 2: 3-11.

Goel, V.L. \& H.M. BeHL. 2001.Genetic selection and improvement of hard wood tree species for fuelwood production on sodic soil with particular reference to Prosopis juliflora. Biomass \& Bioenergy 20: 9-15.

Grundy, I.M., CAmpbell, B.M., Balebereho, S., Cunliffe, R., Tafangenyasha, C., Fergusson, R. \& D. PARRY. 1993. Availability and use of trees in Mutanda resettlement area, Zimbabwe. Forest Ecology \& Management 56: 243-266.

Hall, D.O. 1991. Biomass energy. Energy Policy 19: 711-737.

Kataki, R. \& D. Konwer. 2002. Fuelwood characteristics of indigenous tree species of north-east India. Biomass \& Bioenergy 22: 433-437.

LEACH, G. \& R. MEARNS. 1989. Beyond the fuelwood crisis: people, land and trees in Africa. London: Earthscan.

Leach, M. \& R. Mearns. 1996. The lie of the land: challenging received wisdom on the African environment. Oxford: Currey \& Heinemann.

Luoga, E.J., WitKowski, E.T.F. \& K. BALKwill. 2001. Harvested and standing wood stocks in protected and communal Miombo woodlands of eastern Tanzania. Forest Ecology \& Management 164: 15-30.

MARTIN, G. 1995. Ethnobotany: a methods manual. London: Chapmans \& Hall.

McNeELY, J.A. 2003. Biodiversity in arid regions: values and perceptions. Journal of Arid Environments 54: 61-70.

MudEKWE, J. 1997. Assessing the effect of tree size on the production of harvesting deadwood for fuelwood. M.Sc thesis, University of the Witwatersrand, Johannesburg.

Nagothu, U.S. 2001. Fuelwood and fodder extraction and deforestation: mainstream views in India discussed on the basis of data from the semi-arid region of Rajasthan. Geoforum 32: 319-332.

PANDEY, D. 2002. Fuelwood studies in India: myth and reality. Bogor: CIFOR.

REID, R.S. \& J.E. ELLIS. 1995. Impacts of pastoralists on woodlands in south Turkana, Kenya: livestock mediated tree recruitment. Ecological Applications 5: 978-992.

Shackleton, C.M., Griffin, N.J., Banks, D.I., Mavrandonis, J.M. \& S.E. ShackLeton. 1994. Community structure and species composition along a disturbance gradient in a communally managed South African savanna. Vegetatio 115: 157-167.

SHACKLETON, C.M. 1998. Annual production of harvestable deadwood in semi-arid savannas, South Africa. Forest Ecology \& Management 112: 139-144.

SulLivan, S. 1999. The impacts of people and livestock on topographically diverse open woodand shrub-lands of arid north-west Namibia. Global Ecology \& Biogeography 8: 257-277.

Tietema, T. Dithogo, M. Tibone, C. \& N. MathaLAZA. 1991. Characteristics of eight firewood species of Botswana. Biomass \& Bioenergy 1: 41-46.

VAN DER WALT, P.T.1992. The Richtersveld-a desert paradise. Airlink 2 (1): 4-5.

WALKER, B.H. 1976. An approach to the monitoring of changes in the composition and utilization of woodland and savanna vegetation. South African Journal of Wildlife Research 6: 1-32.

Ward, D., B.T. Ngairorue, A. Apollus \& H. TJIVEZE. 2000. Perceptions and realities of land degradation in arid Otjimbingwe, Namibia. Journal of Arid Environments 45: 337-356.

Williams, A. \& C.M. ShackLeton. 2002. Fuelwood use in South Africa: where to in the 21st century? Southern African Forestry Journal 196: 1-7.

Williamson, G. 2000. Notes on the vegetation and climate of the Richtersveld National Park. Aloe 31: 83-87. 